\title{
Nautakarjatuotannon ympäristövaikutusten arviointi ja sen kehittämistarpeet
}

\author{
Perttu Virkajärvi ja Kirsi Järvenranta \\ Luonnonvarakeskus, Vihreä teknologia, Halolantie 31 A, 71750 Maaninka, \\ etunimi.sukunimi@luke.fi
}

\begin{abstract}
Nautakarjatalous on ollut viime aikoina kovan kritiikin kohteena sekä ympäristökuormituksen että tuotannon eettisen oikeutuksen näkökulmasta. Keskustelu on osa länsimaista ruoantuotannon arvopohjan kyseenalaistamista, joka heijastelee nautakarjatuotannon globaaleja ongelmia. Suomessa ympäristövaikutusten osalta lähestymistapa on usein hyvin Itämerikeskeinen, mutta myös maatalouden kasvihuonekaasupäästöt ja hiilitase ovat nousseet esiin ristiriitaisten tutkimustulosten valossa. Nautakarjataloudella on suuri rooli Suomen elintarvikesektorilla raha- ja ravinnevirtojen, pellon käytön sekä maatalouden työllisyyden osalta. Siksi sen ympäristövaikutusten kokonaisvaltainen tarkastelu on tärkeää.
\end{abstract}

Tarkastelun lähtökohtana on hahmottaa nautakarjatalouden ravinnekierron kokonaisuus ja tarkastella tässä valossa kriittisesti väitteitä suomalaisen nautakarjatalouden ympäristövaikutuksista. Tarkastelumme perustuu uusimpien tieteellisten julkaisujen sekä omien aineistojemme pohjalta laadittuun synteesiin. Taustatietoina käytämme tilastollisia aineistoja mm. viljelykasvien pinta-alasta, eläinmääristä ja maaperästä. Holistisen näkökulman saavuttamiseksi käytämme tarkoitukseen soveltuvia malleja sekä massavirta- ja vaikuttavuuslaskelmia. Vaikutukset jaetaan laajuuden perusteella globaaleihin ja lokaaleihin. Tarkastelumme sisältää ympäristö-, eläinravitsemus-, maaperä, ja kasvinviljelytiedettä sekä limnologiaa. Päämääränä on asettaa kotimaisen nautakarjatuotannon ympäristövaikutukset tärkeysjärjestykseen - mihin ongelmiin meidän kannattaa tarttua ja mihin suuntaan tuotantoa pitäisi kehittää.

Nautakarjatuotannon ympäristövaikutukset syntyvät monimutkaisten takaisinkytkentöjen kautta. Pahimmillaan systeemin osaoptimointi on ympäristönsuojelullisesta näkökulmasta harhaanjohtavaa. Holistinen systeemianalyysi on parempi tapa arvioida tuotannon aiheuttamaa kuormitusta. Se helpottaa myös ristiriitaisten tavoitteiden suhteuttamista toisiinsa. Huomattava osa nautakarjatalouteen kohdistetusta kritiikistä perustuu todellisiin mutta etupäässä ulkomaisissa tuotantosysteemeissä toteutuviin haittoihin kuten suuri vesijalanjälki, eroosio, ylilaidunnus, herbisidien käyttö ja happamoituminen. Suomalaisessa tuotantoympäristössä em. haitat jäävät todistettavasti vähäisemmäksi, mikä perustuu mm. alhaisempaan eläintiheyteen, tilalla tuotettujen rehujen korkeaan osuuteen, nurmenviljelyn edullisiin ympäristövaikutuksiin, vähäisempään maatalousmaan osuuteen maa-alasta ja yhteiskunnan pyrkimyksiin suojella luontoa lainsäädännön avulla. Suomen ympäristöolosuhteet huomioiden esitämme kotimaisen nautakarjatalouden tärkeimmiksi painopisteiksi kasvihuonekaasujen päästön minimoimista koko maassa sekä vesistöpäästöjen vähentämistä etenkin sisävesialueilla. Tulevaisuudessa nautakarjataloutta tulee tarkastella vielä laajemmassa kontekstissa, johon kuuluu globaali ravinnontuotanto ja -tarve, tuotannon eettisyys sekä taloudelliset edellytykset. Tieteellisen tiedon rooli keskustelussa on merkittävä.

Asiasanat: märehtijät, nautakarja, ympäristökuormitus, systeemitarkastelu 


\section{Johdanto}

Nautakarjatalous on ollut viime aikoina Suomessa kovan kritiikin kohteena sekä ympäristökuormituksen että tuotannon eettisen oikeutuksen näkökulmasta (mm. Mattila 2016, WWF 2016, Kauppila ym. 2017, Marttinen 2017). Keskustelu on osa länsimaista ruoantuotannon arvopohjan kyseenalaistamista, joka heijastelee nautakarjatuotannon globaaleja ongelmia (Steinfeld 2006, Leip ym. 2015). Globaalilla tasolla ongelmat ovat monessa suhteessa ilmeisiä, mutta niiden yleistäminen suomalaiseen tuotantotapaan ja luonnonolosuhteisiin ei ole suoraviivaista - molemmat poikkeavat merkittävällä tavalla maailman mittakaavassa yleisimmistä.

Keskustelua vaikeuttaa myös se, että nautakarjan aiheuttamista ympäristövaikutuksista voidaan puhua sekä tuotannon että kuluttajan näkökulmasta, jotka poikkeavat merkittävästi toisistaan erityisesti lokaali-globaali - akselilla: ympäristövaikutukset voivat olla globaaleja, kuten kasvihuonekaasut, tai lokaaleja kuten vesistökuormitus. Kuluttajan näkökulmasta nämä kaikki ovat relevantteja mutta ja kotimaisen tuotannon näkökulmasta kansainvälisesti merkittävien lokaalien vaikutusten yleistäminen voi olla hyvinkin harhaanjohtavaa. Toisinaan kritiikki kohdistuu kaikkeen kotieläintuotantoon eikä kritiikissä erotella eri eläinlajeja ja niiden erilaisia tuotantotapoja toisistaan (Kauppila ym. 2017, Marttinen 2017). Lisäksi keskustelussa on käsitesekaannuksia ja toisinaan tutkimustuloksetkin ovat ristiriitaisia (Newsbrokers 2017).

Nautakarjatalouden ravinnekierto on hyvin monimutkainen kokonaisuus (Saarijärvi 2008, Huhtanen ym. 2009, Kykkänen 2014), joka poikkeaa muiden eläinryhmien ravinnekierrosta. Nautakarjatuotannon ympäristövaikutukset syntyvät monimutkaisten takaisinkytkentöjen kautta. Systeemin osaoptimointi saattaa yhdellä osa-alueella tuottaa erinomaisia tuloksia, mutta olla silti kokonaisvaikutukseltaan ympäristönsuojelullisesti haitallista. Lisäksi ympäristövaikutusten moninaisuus (mm. kasvihuonekaasupäästöt, ravinteiden huuhtoutuminen, happamoittavat ja rehevöittävät päästöt) ja arvoriippuvuus vaikeuttavat niiden arviointia. Tässä mielessä holistinen systeemianalyysi on osaoptimointia parempi tapa arvioida tuotannon aiheuttaman kuormituksen merkitystä (Katajajuuri ym. 2015). Se helpottaa myös ristiriitaisten tavoitteiden keskinäistä suhteuttamista. Ympäristönsuojelun kannalta kokonaisvaltainen tarkastelu on tärkeää, jotta voidaan kohdentaa toimenpiteet tärkeimpiin kohteisiin mahdollisimman kustannustehokkaasti.

Tarkastelemme kotimaisen nautakarjatalouden ympäristövaikutuksia suhteessa globaaleihin ympäristövaikutuksiin. Tarkastelussa pyrimme osoittamaan tärkeimmät erot ja erojen syyt erilaisten systeemien ympäristövaikutusten välille tieteellisten tulosten perustella. Lopuksi pohdimme Suomen nautakarjatalouden tärkeimpien negatiivisten ympäristövaikutusten vähentämisen mahdollisuuksia. Tässä tekstissä emme ota kantaa eläintuotannon eettisiin kysymyksiin emmekä tuotteiden terveysvaikutuksiin. Itsestään selvä lähtökohta on myös se, että eläintuotannon ympäristövaikutusten vähentämisen kannalta merkittävä toimenpide on vähentää eläintuotteiden käyttöä.

\section{Naudanlihantuotannon ympäristöhaitat - globaalin ja kotimaisen tuotannon tilanne}

Globaalissa mittakaavassa nautakarjatalouden ympäristöhaittojen lista on mittava. Keskeinen yhteenveto aiheesta on FAO:n julkaisema Livestock's long shadow (Steinfeld ym. 2006). Yhteenveto esiintyy yleisesti myös kotimaisissa tarkasteluissa (mm. Pesonen ja Huuskonen 2014, Marttinen ym. 2016) ja tässä sitä on käytetty myös taulukon 1 pohjana globaalin tilanteen osalta. Taulukossa tarkastelemme Suomen tilannetta samojen vaikutusluokkien osalta ja 
tarkastelu pohjautuu yleiseen tietoon tuotantosysteemeistä, tieteellisiin tutkimuksiin eri vaikutusluokista, ja muutamin osin logiikkaan. Taulukko on yksinkertaistus laajasta kokonaisuudesta, mutta se helpottaa tuotantosysteemien keskeisten erojen hahmottamista ympäristövaikutusten vakavuuden suhteen. Taulukossa mainitut ympäristövaikutukset ja niiden taustat lähdeviitteineen käsittelemme tekstissä. Taulukossa vertailemme nautakarjatalouden yleisimmin esitettyjen ympäristöhaittojen painottumista globaalisti ja Suomen tyyppisissä olosuhteissa (ts. luonnonolot ja tuotantomenetelmät vastaavat suomalaisia). Vertailu kohdistuu suomalaisten kulutustarpeen täyttämisen aiheuttamiin ympäristöhaittoihin joko tuonnin tai kotimaisen tuotannon kautta. Punainen väri edustaa haittaa, vihreä taas suomalaisen tai Suomentyyppisen tuotannon suhteellista etua verrattuna siihen, että liha tuotettaisiin ongelmaalueilla kuten esim. Etelä-Amerikassa (ks. Steinfeld 2006).

Taulukko 1. Nautakarjatalouden yleisimmin esitettyjen ympäristöhaittojen painottuminen globaalisti ja Suomen tyyppisissä olosuhteissa. Punainen väri edustaa haittaa, vihreä taas suomalaisen tai Suomentyyppisen tuotannon suhteellista etua

\begin{tabular}{|c|c|c|c|}
\hline & $\begin{array}{l}\text { Globaali } \\
\text { tilanne }\end{array}$ & $\begin{array}{l}\text { Suomen } \\
\text { tilanne }\end{array}$ & Miksi Suomi poikkeaa globaalista \\
\hline Kasvihuonekaasupäästöt & & & $\begin{array}{l}\text { Naudanlihantuotannon osuus } \\
\text { vähäisempi }\end{array}$ \\
\hline Rehevöityminen $\mathrm{P}$ & 0 & 00 & Liukoinen $\mathrm{P}$, herkät vedet \\
\hline Rehevöityminen $\mathrm{N}$ & O & & $\mathrm{N}$ merkitys vähäisempi \\
\hline Happamoituminen $\mathrm{N}$ & O & 0 & Laskeuma pieni ja $70 \%$ ulkomailta \\
\hline Vedenkäyttö & 0 & 000 & Vesitase, runsaat vesivarat \\
\hline Monimuotoisuus & & 00 & Nurmi ja ekstensiivinen laidun \\
\hline Ylilaidunnus & 0 & 00 & Ei juurikaan \\
\hline Kasvinsuojelu & & 0 & Nurmilla vähän, ei käytetä soijaa \\
\hline $\begin{array}{l}\text { Maatalousmaan } \\
\text { vaihtoehtoinen käyttö }\end{array}$ & & 0 & Nurmi sopii hyvin Suomen ilmastoon \\
\hline Hiilitase & ○ & O & Hidastaa maan C varojen vähenemistä \\
\hline
\end{tabular}

Lähteet: ks teksti.

Kasvihuonekaasupäästöjen osalta arvioimme, että Suomen merkitys ja osuus ovat suhteessa hieman nautakarjataloudesta globaalisti aiheutuvaa haittaa pienemmät. Yksittäistä nautaa kohti päästöt ovat yhtä haitallisia kuin muualla maailmassa, mutta kokonaishaittaa lieventäviä tekijöitä on useita.

Suomessa ruoka aiheuttaa noin 24\% kokonaiskulutuksen ilmastovaikutuksesta (Risku-Norja ym. 2009). Ruokaketjussa merkittävimmät kasvihuonekaasupäästöt ovat märehtijöiden ruoansulatuksessa vapautuva metaanipäästö $\left(\mathrm{CH}_{4}\right)$, pelloilta ja erityisesti orgaanisilta pelloilta vapautuvat dityppioksidi $\left(\mathrm{N}_{2} \mathrm{O}\right)$ - ja hiilidioksidi $\left(\mathrm{CO}_{2}\right)$-päästöt sekä lannan käsittelystä vapautuvat $\mathrm{CH}_{4}$ - ja $\mathrm{N}_{2} \mathrm{O}$ - päästöt.

Nautojen ruoansulatus perustuu mikrobien hajotustoimintaan, joka tuottaa aina metaania olosuhteista riippumatta. Metaanin määrää voidaan vähentää jonkin verran muuttamalla dieettiä väkirehuvaltaisemmaksi tai lisäämällä dieettiin rasvaa, mutta samalla vähenee nautojen oleellinen etu muihin tuotantoeläimiin verrattuna nimenomaan karkearehun hyödyntäjinä. Märehtijöiden ruoansulatuksen $\mathrm{CO}_{2}$-ekv päästö muodosti 3.5\% Suomen KHK- emissioista vuonna 2014 (Tilastokeskus 2016). Naudanlihan ilmastovaikutus on tästä huolimatta nelin- ja jopa kuusinkertainen sian- ja broilerinlihan ilmastovaikutuksiin verrattuna (de Vries ja de Boer 2010). 
Nautakarjatalous lisää KHK-päästöjä myös lannankäsittelyn kautta (metaani, $\mathrm{N}_{2} \mathrm{O}$ ) mutta sen osuus on vähäisempi, koska kaikkien kotieläinten lannankäsittelyn KHK-päästöt muodostavat maatalouden päästöistä noin 10\% (Tilastokeskus 2017). Sen sijaan eloperäisten maiden raivaaminen pelloiksi lisää huomattavasti Suomen KHK-päästöjä ja on merkittävä haitta. Nurmen viljely orgaanisilla raivioilla on kuitenkin KHK-päästöjen hillinnän kannalta edullisin vaihtoehto (Regina ym. 2014).

KHK-päästöjen vaikutukset ovat globaaleja, joten niiden päästölähteiden sijainnilla ei ole merkitystä. KHK- päästöjen kokonaismäärä on kuitenkin suorassa suhteessa eläinten määrään ja Suomessa nautojen määrä on suuriin tuottajamaihin verrattuna varsin vähäinen sekä absoluuttisesti että pinta-alaa kohti laskettuna. Näin ollen suomalaisen märehtijätuotannon vaikutus globaaliin päästökertymään on pieni. Tilastokeskuksen (2016) ja FAOSTATin (2014) laskelmien perusteella Suomen osuus märehtijöiden ruoansulatuksen globaalista KHKpäästöstä oli $0.14 \%$. Samoin KHK-päästöjen vähentämispotentiaali on globaalissa mittakaavassa absoluuttisena arvona vähäinen.

Nautakarjatalouden KHK-päästöjen suhteellinen merkitys realisoituu kulutuksen kautta. Lihan ja maidon osuus keskimääräisen suomalaisen koko kulutuksen KHK-päästöistä on noin 5,2\% ja niiden jättäminen pois ruokavaliosta vähentäisi ruokavalion $\mathrm{CO}_{2}$-päästöjä 23\% tavanomaiseen ruokavalioon verrattuna (Risku-Norja ym. 2009). Taulukossa 2 on verrattu naudanlihasta luopumisen KHK-päästövähennystä eräiden muiden toimenpiteiden aiheuttamaan vähennykseen. Taulukon perusteella naudanlihasta luopuminen vähentää merkittävästi kulutuksen KHK- päästöjä muiden toimenpiteiden ohella.

Taulukko 2. Naudanlihasta luopumisen ja muutamien kirjallisuudessa esiin nostettujen toimenpiteiden aiheuttama $\mathrm{CO}_{2}$ ekv - vähennys vuositasolla sekä niiden suhteellinen merkitys naudanlihasta luopumiseen verrattuna.

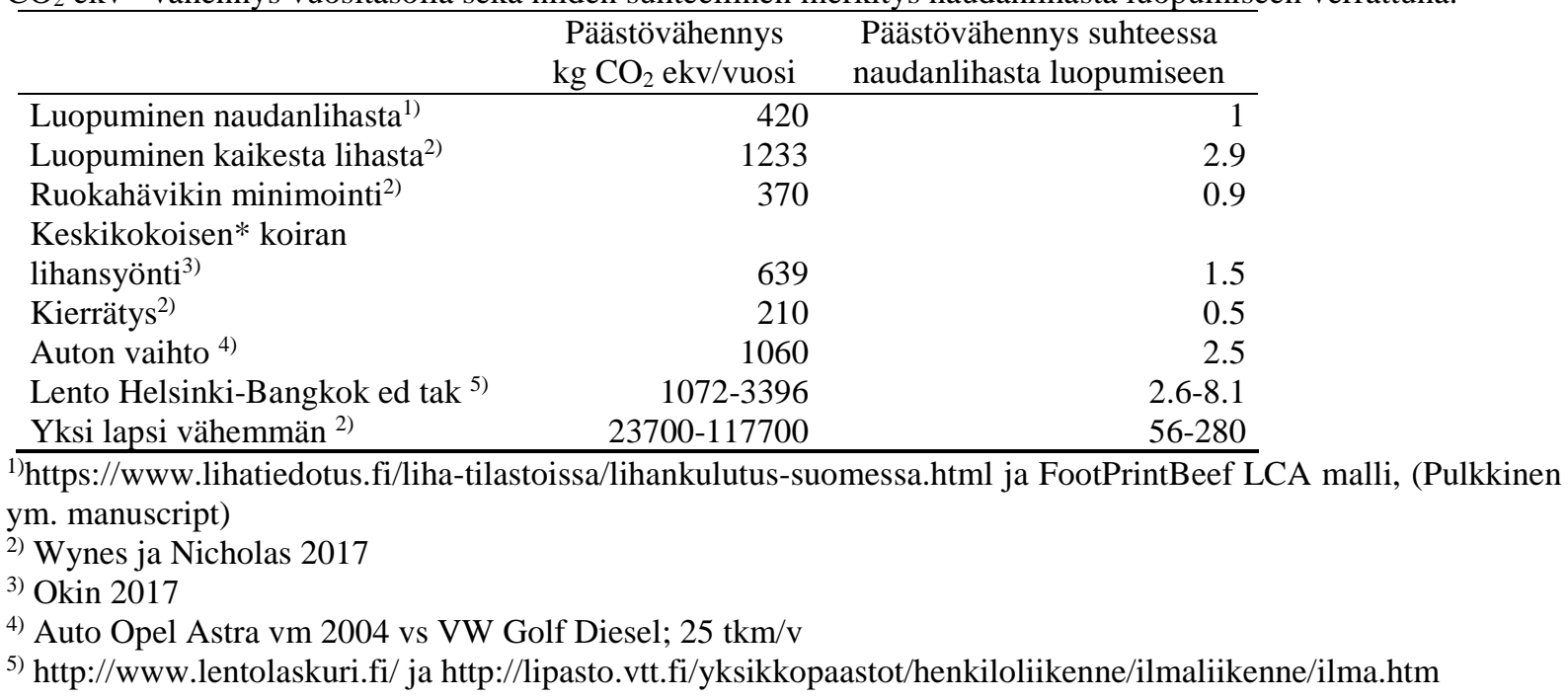

Rehevöittävistä vaikutuksista puhuttaessa tarkoitetaan usein vesistöjen rehevöitymistä, mikä johtuu levien kasvua edistävien ravinteiden eli typen $(\mathrm{N})$ ja fosforin $(\mathrm{P})$ liiallisesta määrästä vesistöissä. Globaalin tason suuret eläintuotantoyksiköt aiheuttavat ravinteiden alueellista kertymää, mikä lisää niiden huuhtoutumisriskiä, varsinkin jos peltopinta-ala ei riitä lannan levittämiseen tai lannan varastoinnissa ja käsittelyssä on ongelmia. Suurten tuotantoyksiköiden aiheuttamia ongelmia esiintyy erityisesti kehittyneillä alueilla kuten USA:ssa ja EU:ssa (Steinfeld ym. 2006, Leip 2015). 
Suomessa nautakeskittymät ovat suhteellisen pieniä ja ruokinta perustuu suurelta osin kotovaraisiin rehuihin, joten eläinten ja pelto-alan suhde (ny/ha) pysyy matalana. Maidontuotantotiloilla eläintiheys on 0,59 ny/ha (2012), mitä pidämme varsin alhaisena verrattuna suuriin eurooppalaisiin tuottajamaihin (Virkajärvi ym. 2015). Säilörehua ei juurikaan voi ostaa markkinoilta, joten peltoa varataan yhtä eläinyksikköä kohden niin, että rehu todennäköisesti riittää sisäruokintakauden (myös ympärivuotisen) yli. Ruokinnan pintaalavaatimuksen seurauksena nautatiloilla on myös yleensä riittävästi lannanlevitysalaa, jota edellytetään mm. uusien navetoiden perustamisluvissa (Kauppila ym. 2017). Lisäksi lannanlevitystä säätelee myös koko maan kattava nitraattiasetus (VnA 1250/2014) sekä vapaaehtoinen ympäristökorvausjärjestelmä (VnA 235/2015). Vaikka yleisesti maatalous vastaa n. 60\%:sta vesistöjen fosforikuormituksesta (Ekholm 1998) ja 50\%:ia typen kuormituksesta (Huhtanen ym. 2009) on maatalouden osuus Vuoksen vesistön - jonka pohjoisosissa on Pohjois-Savon nautakeskittymä -kokonaisfosforikuormituksesta on 33\% ja kokonaistypestä 24\% (Kotanen ym. 2010).

Säädöstenmukainen lannanlevitys ei näissä olosuhteissa yleensä aiheuta maan fosforipitoisuuden nousua: lypsykarjatilojen fosforin porttitase tase oli vielä 2000-luvun alussa $+12 \mathrm{~kg} \mathrm{P} \mathrm{ha}^{-1} \mathrm{v}^{-1}$ (Virtanen ja Nousiainen 2005) ja taseeseen perustuvat maan P-luvun kehitystä ennustavat mallit (Ekholm ym. 2005, Uusitalo ym. 2016), osoittavat saman kuin käytännön havainnot: nautakarjatiloilla peltojen P-luku on maltillinen ja mikäli tilan satotaso on korkea, ovat P-luvut laskusuunnassa. Myös karjan kivennäisten P- pitoisuutta alennettiin 2000-luvun alussa, jonka johdosta porttitaseet ovat todennäköisesti alentuneet entisestään (Huhtanen ym. 2009).

Toisaalta nurmiviljelyssä lantaa ja lannoitteita levitetään usein maan pintaan tai pintakerroksen, missä niiden liukoiset ravinteet ovat alttiina huuhtoutumiselle (Turtola ja Kemppainen 1998). Suomessa sadanta ylittää haihdunnan ja kasvusto voi hyödyntää ravinteita vain lyhyellä kasvukaudella. Talviset ilmasto-olosuhteet lisäävät entisestään liukoisten ravinteiden huuhtoutumisriskiä (Räty ym. 2014), mikä näkyy vesistöjen rehevöitymisenä jo melko vähäisenkin kuormituksen seurauksena. Liuennut P on eroosiofosforista poiketen suoraan leville käyttökelpoista ja rehevöittävää (Ekholm 1998).

Vesistöjen rehevöitymisongelmat näkyvät ennen kaikkea paikallisina, lähellä päästölähdettä. Sisä-Suomen järvistä 99-97\% on P-rajoitteisia, rannikkoalueilla vastaava luku on n. 90\%. SisäSuomessa vesistöt muodostavat järviketjuja, joissa järvialtaat kytkeytyvät toisiinsa joko suoraan tai lyhyiden jokiuomien kautta. Keskimääräinen viipymäaika järvessä on noin kaksi vuotta, joskin vaihtelua on paljon (Niemi ym. 2004). Viipymäajasta johtuen rehevöityminen näkyy eniten järvessä, johon kuormitus kohdistuu ja merkittävä osa ravinnekuormituksen vuoksi lisääntyneestä leväkasvustosta ehtiikin sedimentoitua järven pohjaan jo tässä vaiheessa. Pohjalla hajoava orgaaninen aines saattaa kiihdyttää rehevöitymistä, jos happikadon seurauksena pohjasedimentistä alkaa vapautua liuennutta fosforia (sisäinen kuormitus käynnistyy).

Esimerkiksi voimakkaalla maatalousalueella Iisalmen reitin latva-alueilla sijaitseva järviketju Kangaslammesta Kirmanjärven Luusuaan pidättää lähes $80 \%$ siihen kohdistuvasta

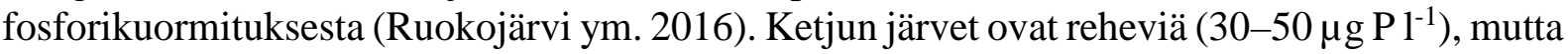
haitta ei sedimentaation vuoksi ulotu Pohjois-Kallavettä pidemmälle. Etelä-Kallavedellä Ppitoisuus on ja laskenut tasolle 15-25 $\mu \mathrm{g} \mathrm{P} \mathrm{l}^{-1}$. Reittiä alaspäin tultaessa veden fosforipitoisuus laskee edelleen ja Vuoksen vesistön Suomen puoleisessa päätepisteessä veden laatu on erinomainen ja sen P-pitoisuus vain 5-10 $\mu \mathrm{g} \mathrm{l}^{-1}$. Ilman sedimentaatiota kuormituksen 
aiheuttama sekoituspitoisuus olisi vielä Savonlinnan tasalla yli $50 \mu g \mathrm{P} \mathrm{l}^{-1}$ (Heitto ja Saarijärvi 2001).

Vesistöjen kyky sitoa fosforia on kuitenkin rajallinen. Jos järvi on päässyt rehevöitymään, sisäisen kuormituksen prosessit voivat purkaa järveen kertynyttä fosforia vielä pitkään sen jälkeen, kun ulkoisen kuormituksen määrä on saatu vähennettyä kriittisen rajan alapuolelle (Vollenweider 1975). Nautakarjatuotannosta ja nurmiviljelystä peräisin oleva liuenneen fosforin kuormitus (Turtola ja Kemppainen 1998, Järvenranta ym. 2014, Räty ym. 2014) rehevöittää vesistöjä erityisesti paikallisella tasolla. Ongelmaa ei ole saatu ratkaistua riittävällä tehokkuudella, ja kyseessä on Suomen kannalta merkittävä haaste.

Happamoitumisen kannalta keskeisin yhdiste ruoantuotannossa on ammoniakki. Maatalous aiheuttaa 85-95\% ammoniakkipäästöistä (Bartnicki ja Valiyaveetil 2009). Kotieläintuotannon korkeaa osuutta ammoniakkipäästöistä korostetaan yleisesti Suomessa (Grönroos 2014), vaikka todelliset negatiiviset vaikutukset aiheutuvat laskeman absoluuttisesta määrästä $\mathrm{kg}^{-1} \mathrm{ha}^{-1}$ vuosi${ }^{1}$ eivätkä prosentuaalisesta osuudesta. Suomen ammoniakkipäästöt olivat vuonna 2014 yhteensä noin 37 kilotonnia (kt) eli n. 31 kt NH${ }_{3}-\mathrm{N} \mathrm{v}^{-1}$ (Suomen ympäristökeskus 2014). Maatalouden osuus kokonaispäästöistä oli noin $90 \%\left(28 \mathrm{kt} \mathrm{v}^{-1}\right)$. Kun koko Suomen maatalouden ammoniumtyppipäästöt (28 kt NH $\mathrm{NH}_{3}-\mathrm{N} \mathrm{v}^{-1}$ ) jaetaan maan pinta-alalla $338000 \mathrm{~km}^{2}$, päästöjen määrä on vain n. $0,83 \mathrm{~kg}^{-1} \mathrm{NH}_{3}-\mathrm{N} \mathrm{ha}^{-1} \mathrm{v}^{-1}$. Uusi, tarkennettu, laskentamalli (Grönroos ym. 2017) arvioi päästöt vielä n. 10\% alemmiksi kuin tässä esitetyt luvut.

Olemme sitoutuneet kansainväliseen ilmastosopimukseen, jossa Suomen vähennystavoite ammoniakin osalta on $20 \%$ eli määrällisesti noin $0,16 \mathrm{~kg}^{-1} \mathrm{NH}_{3}-\mathrm{N} \mathrm{ha}^{-1} \mathrm{v}^{-1}$ laskettuna vuoden 2014 laskeumaluvusta. Määrä vaikuttaa lähes merkityksettömältä, etenkin kun happamoitumisen kriittisen tason ylittävien herkkien alueiden ala on pienentynyt Suomessa noin 90 prosenttia ja kriittinen kuormitus ylittyy alle 2 prosentilla herkistä alueista (Suoheimo 2015). Toisaalta, Suomen koko ammoniakkilaskeumasta (3-4 kg NH $\mathrm{ha}^{-1} \mathrm{v}^{-1}$ ) noin $70 \%$ tulee ulkomailta (Pipatti 1990) ja siltä osin sopimus on Suomen kannalta edullinen. Vaikka ammoniakki on yleisesti haitallinen myös ilmansaasteena, se tuskin on merkityksellinen Suomessa, koska sen pitoisuudet ovat olleet Ilmatieteen laitoksen mittauksissa varsin alhaisia esimerkiksi Englantiin tai Keski-Eurooppaan verrattuna (Lovén ym. 2015).

Vesijalanjäljellä viitataan makeanveden kulutukseen (sininen vesijalanjälki), joka ei palaudu enää kiertoon puhtaana. Vihreä vesi kuvaa sadantaa ja harmaata jätevettä. Naudanlihan ja maidon tuotanto kuluttaa runsaasti vihreää vettä mutta alueesta riippuen myös sinistä, mm. rehuntuotantoon käytetyn kasteluveden muodossa. Suomessa on runsaasti makeaa vettä käytettävissä omaan kulutukseen ja tuotantoon eikä suomalaisten tuotteiden osalta vesijalanjälki ole yleensä ongelma (Lehtinen ja Usva 2011, Ridoutt ym. 2012). Se, että Suomessa säästetään vettä lihan- tai maidontuotannossa tai ei muuta globaalia vesitasetta paremmaksi. Sen sijaan suomalaisetkin kuluttavat tuontilihan- ja -rehujen ja muiden tuontituotteiden muodossa muiden, myös vesivarannoiltaan köyhien alueiden, vesivaroja.

Biodiversiteetti voi nautakarjatalouden seurauksena tuotantotavasta riippuen joko lisääntyä tai vähentyä. Globaalilla tasolla luonnontilaisten alueiden muuttaminen viljelymaaksi ja eläinten laidunmaaksi aiheuttaa uhan luonnon monimuotoisuudelle. Vaikutukset kohdistuvat monimuotoisuuden kaikille tasoille eli lajien sisäiseen, lajien väliseen ja ekosysteemitason monimuotoisuuteen (mm. Steinfeld ym. 2006). Ekstensiivisen nautakarjatuotannon merkittävimmät vaikutukset ovat metsien pirstoutuminen, aavikoituminen ja kasvilajien yksipuolistuminen. Intensiivisen tuotannon biodiversiteettiä vähentävät vaikutukset puolestaan 
ovat yhteydessä tuotannon tehokkuuteen sisältäen alueesta riippuen mm. rehevöitymisestä tai eroosiosta johtuvan lajiston yksipuolistumisen, kemiallisen kasvinsuojelun vaikutukset sekä myös tuontirehujen tuotannon vaikutukset (erityisesti soijan viljely). Sademetsien raivaaminen joko laitumeksi tai soijantuotantoon on uhka biodiversiteetille (Steinfeld ym. 2006).

Suomessa ja muilla vastaavilla tuotantoalueilla em. uhat eivät realisoidu. Ensinnäkin Suomessa soijan käyttö nautakarjan (lihanaudat, maidontuotanto) rehuna on olematonta. Toiseksi, vaikka intensiivinen nurmituotanto ei itsessään ole erityisen lajirunsas, monivuotiset (ts. harvoin muokattavat) nurmet tarjoavat suotuisan elinympäristön useille rikkakasvilajeille, niveljalkaisille, maaperäeliöille ja linnuille (Heliölä ym. 2009, Hokkanen ym. 2006, Nieminen ym. 2011). Erityisen hyvin tämä näkyy laitumilla (Mikola ym. 2009). Nurmet lisäävät monimuotoisuutta myös perinnebiotoopeissa, joissa viihtyy 25\% uhanalaisista eliöistä (Pykälä 2007, Heliölä ym. 2009).

Eri vaikutusten suhteellistamisessa on hyvä muistaa, että Suomessa kulutetun ruoan maankäytön aiheuttamasta luonnon monimuotoisuuden vähenemisestä kuitenkin yli 90 prosenttia tapahtuu ulkomailla. Suurimmat vaikutukset ovat tuotteilla, joita tuodaan Brasiliasta, Intiasta, Kolumbiasta ja Indonesiasta. Kasvien osalta suurimmat vaikutukset on kahvilla, kaakaolla, sokerilla ja soijalla. Vedenkäyttöön liittyvästä luonnon monimuotoisuuden vähenemisestä yli 99\% tapahtuu ulkomailla. Ongelmallisimpia ovat riisi ja sitrushedelmät Espanjasta, USA:sta ja Egyptistä (Sandström ym. 2017).

Ylilaidunnus on vakava uhka etenkin Afrikassa ja Keski-Aasiassa (aridi/semiaridi; Steinfeld ym. 2006). Suomen nautakarjatuotannossa ylilaidunnusta ei esiinny merkittävästi.

Kasvisuojelu on erityisen voimakasta soijan ja maissin viljelyssä. Suomessa kasvinsuojeluaineita ei juuri käytetä nurmituotannossa lukuun ottamatta nurmikierron päätevaihetta, jossa nurmi tuhotaan glyfosaatilla ennen kyntämistä. Viljojen ja rypsin osalta kasvinsuojeluaineiden käyttö on yleistä, mutta tämä liittyy myös suoraan ihmisravinnoksi käytettävään viljaan. Lihakarja ei juuri tarvitse lisävalkuaista perusrehujen lisäksi.

Maatalousmaan vaihtoehtoinen käyttö -ongelman taustana on lihantuotannon huono energiatase verrattuna suoraan ravinnoksi käytettäviin kasveihin. Maapallon maatalousalueesta $40 \%$ on sellaista, jota ei voida käyttää muuhun kuin nurmituotantoon (savannit, vuoristot jne.), joten globaalisti vain osa nurmista on potentiaalisia suoraan ihmisravinnoksi kelpaavien kasvien viljelyyn. Suomessa nurmi on suhteellisesti kilpailukykyinen kasvi verrattuna esim. palkokasveihin, viljoihin tai öljykasveihin, joiden satoa rajoittavat ja viljelyriskiä lisäävät mm. viileä ilmasto, alhainen säteilyn intensiteetti ja lyhyt kasvukausi. Tämä on yksi syy miksi Suomessa maatalouden tuloista on peräisin nurmipohjaisista tuotantomuodoista (maito, naudanliha; Virkajärvi ym. 2015).

Euroopassa (30 maata) vuonna 2015 keskimääräinen eläimille käytettyjen antibioottien myynti oli 135.5 mg/PCU (Population Correction Unit). Suomessa populaatiokorjattu kulutus vuonna 2015 oli 20 mg/PCU eli eurooppalaisella mittapuulla meillä käytetään hyvin vähän (85\% vähemmän) mikrobilääkkeitä tuotantoeläimille (EMA/184855/2017) ja niiden käyttö on suunnattu eläinten sairauksien hoitoon, ei ennaltaehkäisyyn. 


\section{Johtopäätökset}

Naudanlihan ja maidon tuotantosysteemit ovat monimutkaisia kokonaisuuksia, minkä vuoksi nautakarjan ympäristövaikutusten arvioinnissa holistinen lähestymistapa on usein eduksi, koska sen avulla voidaan ottaa huomioon systeemin erilaiset takaisinkytkennät ja vaikutusluokat. Erilaisten ympäristövaikutusten ristiriidat johtavat arvovalintoihin ja tapauskohtaisiin ratkaisuihin. Eri eläinlajien erottaminen on oleellista vaikutusten arvioinnin ja ympäristöhaittojen ehkäisyn kannalta.

Edellä vertasimme nautakarjatalouden globaaleja ja kotimaisia ympäristövaikutuksia ja löysimme merkittäviä eroja useimmissa vaikutusluokissa. Niinpä sovellettaessa ulkomaisia tutkimustuloksia ympäristövaikutusten osalta Suomeen täytyy olla kriittinen. Kyse ei ole puolustelusta eikä oikeuttamisesta vaan luonnontieteellisestä todellisuudesta. Tärkeimpiä tekijöitä, joiden vuoksi monet globaalit negatiiviset ympäristövaikutukset ja -uhat eivät toteudu kansainvälisessä mittakaavassa suomalaisessa tuotantoympäristössä ovat ensinnäkin pienempi eläinmäärä suhteessa pelto-alaan ja pellon tuottoon, sekä pieni peltoala suhteessa koko maaalaan. Toiseksi, suuri kotoisten rehujen ja etenkin nurmen suhteellisen korkea osuus ruokinnassa on eduksi tasapainoisen ravinnekierron lisäksi myös, koska nurmen edulliset ympäristövaikutukset kompensoivat jonkin verran märehtijöiden aiheuttamia metaani- ja ravinnepäästöjä. Suomen luonnonolot suosivat nurmenviljelyä ja sitä kautta nautakarjataloutta ja lisäksi Suomen pinta- ja pohjavesivarat ovat runsaat. Soijan käyttö nautojen ruokinnassa on lähes olematonta. Naudanlihantuotannon tuotekohtaisia päästöjä vähentää myös se, että Suomessa naudanliha tulee suurelta osalta lypsylehmistä ja niiden sonnivasikoista, jolloin osa kuormituksesta jyvittyy maidontuotannolle. Suomessa myös yhteiskunnan arvot ja lainsäädäntö on säädellyt maataloustuotantoa, etenkin 1990 -luvulta lähtien, mikä on vähentänyt negatiivisia ympäristövaikutuksia oleellisesti.

Tärkeimmät nautakarjatalouden negatiiviset ympäristövaikutukset, joihin Suomessa kannattaa keskittyä, ovat vesistöjen rehevöityminen sekä kasvihuonekaasupäästöjen vähentäminen. Nurmiviljelyssä ja siihen sisältyvässä karjanlannan käytössä etenkin liukoisen fosforin rooli huuhtoutumisessa on merkittävää ja sen vähentäminen perustuu useiden eri keinojen käyttöön. Kasvihuonekaasupäästöjen vähentäminen on globaali haaste, johon voidaan vaikuttaa vähentämällä sekä tuotekohtaista kuormitusta $\left(\mathrm{CO}_{2}\right.$-ekv/kg tuotetta) että tuotteiden kokonaiskulutusta. Kuluttajan kannalta on hyvä tietää erilaisten vähennyskeinojen suhteellinen merkitys.

\section{Kirjallisuusviitteet}

Bartnicki, J. \& Valiyaveetil, S. 2009. Estimation of atmospheric nitrogen deposition to the Baltic Sea in the periods 1997-2003 and 2000-2006. Summary Report for HELCOM. Meteorological Synthesizing Centre-West (MSC-W) of EMEP.

de Vries M. \& de Boer, I.J.M. 2010. Comparing environmental impacts for livestock products: A review of life cycle assessments. Livestock Science 128: 1-11.

Ekholm, P. 1998. Algal available phosphorus originating from from agriculture and municipalities. University of Helsinki. Department of Limnology and Environmental protection. Diss. $67 \mathrm{~s}$.

Ekholm, P., Turtola, E., Grönroos, J., Seuri, P. \& Ylivainio, K. 2005. Phosphorus loss from different farming systems estimated from soil surface phosphorus balance. Agriculture, Ecosystems and Environment 110: 266-278. EMA 2017. European Medicines Agency, European Surveillance of Veterinary Antimicrobial Consumption, 2017. 'Sales of veterinary antimicrobial agents in 30 European countries in 2015'. (EMA/184855/2017)

FAOSTAT 2014. Food and agriculture data. Enteric Fermentation. Food and Agriculture Organization of the United Nations (FAO) Statistics. http://www.fao.org/faostat/en/\#data/GE 
Grönroos, J. 2014. Maatalouden ammoniakkipäästöjen vähentämismahdollisuudet ja -kustannukset. Ympäristöministeriön raportteja 26. $92 \mathrm{~s}$.

Grönroos, J. Munther, J \& Luostarinen, S. 2017. Calculation of atmospheric nitrogen and NMVOC emissions from Finnish agriculture. Description of the revised model. Reports of the Finnish Environment Institute 37 | 2017. $60 \mathrm{~s}$.

Heitto, L. \& Saarijärvi, E. 2001. Ravinteet ja rehevyys Kiuruvedeltä Savonlinnaan 1990-luvun lopulla. Teoksessa: Grönlund, E., Viljanen, M., Juvonen, P. \& Holopainen, I.J. (toim.). Suurjärviseminaari 2001 Ympäristö ja yhteiskunta. Joensuun yliopisto, Karjalan tutkimuslaitoksen julkaisuja 133: 176-182.

Heliölä, J., Lehtomäki, J., Kuussaari, M., Tiainen, J., Piha, M., Schulman, A., Lehtonen, H., Miettinen, A. \& Koikkalainen, K. 2009. Luonnoltaan arvokkaat maatalousalueet Suomessa - määrittely, seuranta ja hoidon taloudelliset edellytykset. Maa- ja metsätalousministeriö 1/2009.

Hokkanen, T. J., Hokkanen, H. \& Virkajärvi, P. 2006. Laidunnuksen vaikutus maakiitäjäislajistoon Tohmajärven laidunkokeessa. In: Huuskonen, A. (toim.). LUMOLAIDUN: Maisemalaiduntaminen luonnon monimuotoisuuden lisääjänä - tasapaino monimuotoisuuden ja tuottavuuden välillä. Maa- ja elintarviketalous 79 : 245-260. http://www.mtt.fi/met/pdf/met79.pdf.

Huhtanen, P., Nousiainen, J., Tuori, M. \& Turtola, E. 2009. Maitotilan fosforikierronmallintaminen. In Turtola, E \& Ylivainio, K. (toim.). Suomen kotieläintalouden fosforikierto - säätöpotentiaali maatiloilla ja aluetasolla. Maa ja elintaviketalous 138: 6-33.

Järvenranta K., Virkajärvi P. \& Heinonen-Tanski H. 2014. The flows and balances of P, K, Ca and Mg on intensively managed Boreal high input grass and low input grass-clover pastures. Agricultural and Food Science 23: 106-117.

Katajajuuri, J.-M., Pulkkinen, H., Hietala, S., Järvenranta, K., Virkajärvi, P., Nousiainen, J. I. \& Huuskonen, A. 2015. A holistic, dynamic model to quantify and mitigate the environmental impacts of cattle farming. Advances in Animal Biosciences 6: 35-36.

Kauppila, J., Ekholm, P., Niskanen, O., Valve, H. \& Iho, A. 2017. Muuttuva kotieläintalous ja vesistökuormituksen sääntely. Ympäristöpolitiikan ja -oikeuden vuosikirja 10: 227-273.

Kotanen, J., Manninen, P. Petäjä-Ronkainen, A. \& Panula-Ontto-Suuronen, A. 2010. Vuoksen vesienhoitoalueen vesienhoitosuunnitelma vuoteen 2015. Sastamala 2010. 205 s.

Kykkänen, S., Virkajärvi, P., Saarijärvi, K. \& Kurppa, S. 2014. Nurmiviljelyn ympäristövaikutusten kokonaisvaltainen mittaaminen. Maataloustieteen Päivät 2014, 8.-9.1.2014 Viikki, Helsinki: esitelmä- ja posteritiivistelmät / Toim. Kuisma, R., Schulman, N., Kymäläinen, H.-R. \& Alakukku, L. Suomen maataloustieteellisen seuran tiedote 31: 197.

Lehtinen, H. \& Usva, K. 2011. Lähestymistapoja elintarvikkeiden vesijalanjäljen arvioimiseksi. Kirjallisuuskatsaus. MTT raportti 37. $60 \mathrm{~s}$.

Leip, A., Billen, G., Garnier, J., Grizzetti, B., Lassaletta, L., Reis, S., Simpson, D., Sutton, M., de Wries, W., Weiss, F. \& Westhoek, H. 2015. Impacts of European livestock production: nitrogen, sulphur, phosphorus and greenhouse gas emissions, land use, water eutrophication and biodiversity. Environmental Research Letters 10.

Lovén, K., Tarvainen, V., Komppula, B., Hannuniemi, H., Makkonen, U. \& Hakola, H. 2015. Suurten polttolaitosten vetykloridin $(\mathrm{HCl})$ ja ammoniakin $\left(\mathrm{NH}_{3}\right)$ BAT-päästötasojen terveys- ja ympäristövaikutukset. Ilmanlaatu ja energia asiantuntijapalvelut 2015. Ilmalaatuselvitys. $51 \mathrm{~s}$.

Marttinen, S., Venelampi, O., Iho, A., Koikkalainen, K., Lehtonen, E., Luostarinen, S., Rasa, K., Sarvi, M., Tampio, E., Turtola, E., Ylivainio, K., Grönroos, J., Kauppila, J., Koskiaho, J., Valve, H., Laine-Ylijoki, J., Lantto, R., Oasmaa, \& A., zu Castell-Rüdenhausen, M. 2017. Kohti ravinteiden kierrätyksen läpimurtoa. Nykytila ja suositukset ohjauskeinojen kehittämiseksi. Luonnonvara- ja biotalouden tutkimus 45/2017. Luonnonvarakeskus, Helsinki. 45 s.

Mattila, H. 2016. Vähemmän lihaa: Kohti kestävää ruokakulttuuria. Helsinki: Gaudeamus. 223 s.

Mikola, J., Setälä, H., Virkajärvi, P., Saarijärvi, K., Ilmarinen, I., Voigt, W. \& Vestberg, M. 2009. Defoliation and patchy nutrient return drive grazing effects on plant and soil properties in a dairy cow pasture. Ecological Monographs 79: 221-244.

Niemi J., Lepistö, L., Mannio, J., Mitikka, S. \& Pietiläinen, O.-P. 2004. Quality and trends of inland waters. In: Inland and Coastal Waters of Finland. Edited by Eloranta P. University of Helsinki. 137 s.

Nieminen, M., Ketoja, E., Mikola, J., Terhivuo, J., Sirén, T. \& Nuutinen, V. 2011. Local land use effects and regional environmental limits on earthworm communities in Finnish arable landscapes. Ecological Applications 21: 3162-3177.

Newsbrokers 2017. Ilmastonmuutos ja naudanlihan tuotanto Suomessa. Asiantuntijahaastatteluja 2016-2017. Newsbrokers Silent Reportage tm XLII 53 p.

Okin, G.S 2017. Environmental impacts of food consumption by dogs and cats. PLos ONE 12(8):e0181301. http://journals.plos.org/plosone/article?id=10.1371/journal.pone.0181301

Pesonen, M. \& Huuskonen, A. 2014. Naudanlihantuotannon ympäristövaikutukset - kirjallisuusselvitys. MTT Raportti 156. 134 s. 
Pipatti, R. 1990. Ammoniakkipäästöt ja -laskeuma Suomessa. Valtion teknillinen tutkimuskeskus. Tutkimuksia 711. Espoo $41 \mathrm{~s}$.

Pykälä, J. 2007. Maintaining plant species richness by cattle grazing: mesic semi-natural grasslands as focal habitats. Publications in Botany from the University of Helsinki 36.

Regina K., Lehtonen H., Palosuo T. \& Ahvenjärvi S. 2014 Maatalouden kasvihuonekaasupäästöt ja niiden vähentäminen. MTT Raportti 127. 43 s.

Ridoutt, B.G., Sanguansri, P., Freer, M., \& Harper G.S. 2012. Water footprint of livestock: comparison of six geographically defined beef production systems. The International Journal of Life Cycle Assessment 17:165-175.

Risku-Norja, H., Kurppa, S. \& Helenius, J. 2009. Dietary choices and greenhouse gas emissions - assessment of impact of vegetarian and organic options at national scale. Progress in Industrial Ecology - An International Journal 6: 340-354.

Ruokojärvi, A., Koski-Vähälä, J. \& Saarijärvi, E. 2016. Maatalouden vesistökuormituksen vähentäminen kustannustehokkaasti? Maataloustieteen Päivät 2016, 12-13.1.2016 Viikki, Helsinki: esitelmä- ja posteritiivistelmä. Alakukku L., Schulman N. \& Puhakainen T. (toim.) Suomen maataloustieteellisen seuran tiedote 32. $297 \mathrm{~s}$.

Räty, M., Järvenranta, K., Virkajärvi P., Saarijärvi E. \& Kröger, H. 2014. Jatkuvatoiminen seurantaverkosto Kirmanjärven valuma-alueella. Maataloustieteen Päivät 2014, 8.-9.1.2014 Viikki, Helsinki: esitelmätiivistelmät. Kuisma, R., Schulman, N., Kymäläinen, H.-R. \& Alakukku, L. (toim.). 7 s.

Saarijärvi, K. 2008. Nitrogen cycling on intensively managed boreal dairy pastures. Doctoral dissertation. Agrifood Research Reports 134. MTT Agrifood Research Finland, Jokioinen, Finland. 134 p.

Sandström, V., Kauppi, P.E., Scherer, L. \& Kastner, T. 2017. Linking country level food supply to global land and water use and biodiversity impacts: The case of Finland. Science of the Total Environment 575: 33-40.

Steinfeld, H., Gerber, P., Wassenaar, T., Castel, VC., Rosales, M. \& de Haan, C. 2006. Livestock's long shadow. FAO, Rome. 390 s.

Suoheimo, P., Grönroos, J., Karvosenoja, N., Petäjä, J., Saarinen, K., Savolahti, M., \& Silvo, K. 2015. Päästökattodirektiiviehdotuksen ja keskisuurten polttolaitosten direktiiviehdotuksen toimeenpanon vaikutukset Suomessa. Suomen ympäristökeskuksen raportteja 6 /2015.

Suomen ympäristökeskus 2014. Ilman epäpuhtauksien päästöt. Viitattu 8.1.2018. http://aedb.apef-library.fi. Tilastokeskus 2016. Suomen virallinen tilasto (SVT): Kasvihuonekaasut. ISSN=1797-6049. Suomen kasvihuonekaasupäästöt 2016. Helsinki: Tilastokeskus. http://www.stat.fi/til/khki/2016/khki_2016_2017-1208 kat_001_fi.html

Tilastokeskus 2017. Suomen kasvihuonekaasupäästöt 1990-2016. 70 s.

Turtola E. \& Kemppainen E. 1998. Nitrogen and phosphorus losses in surface runoff and drainage water after application of slurry and mineral fertilizer to perennial grass ley. Agricultural and Food Science in Finland 7: 569-581.

Uusitalo, R., Hyväluoma, J., Valkama, E., Ketoja, E., Vaahtoranta, A., Virkajärvi, P., Grönroos, J., Lemola, R., Ylivainio, K., Rasa, K. \& Turtola, E. 2016. A Simple Dynamic Model of Soil Test Phosphorus Responses to Phosphorus Balances. Journal of Environmental Quality 45: 977-983.

Virkajärvi, P., Rinne, M., Mononen, J., Niskanen, O., Järvenranta, K., \& Sairanen, A. 2015. Dairy production systems in Finland. Grassland Science in Europe 20: 51-66.

Virtanen H. \& Nousiainen J. 2005. Nitrogen and phosphorus balances on Finnish dairy farms. Agricultural and Food Science 14: 166-180.

VNa 1250/2014. Valtioneuvoston asetus eräiden maa- ja puutarhataloudesta peräisin olevien päästöjen rajoittamisesta. http://www.finlex.fi/fi/laki/alkup/2000/20000461

VNa 235/2015. Valtioneuvoston asetus ympäristökorvauksesta.

http://www.finlex.fi/fi/laki/alkup/2015/20150235

Vollenweider, R.A. 1975. Input-output models: With special reference to the phosphorus loading concept in limnology. Schweierische Zeitschrift fur Hydrologie-Swiss Journal of Hydrology 37: 53-84.

WWF 2016. WWF:n Lihaopas. Vähemmän ja parempaa. https://wwf.fi/lihaopas/.

Wynes, S \& Nicholas, K.A. 2017. The climate mitigation gap: education and government recommendations miss the most effective individual actions. Environmental Research Letters 12. 